\title{
Effect of the High Temperature Resistant Nano-Coolant on Automotive Engine Operation
}

\author{
Xin Sha ${ }^{1}$, Lu Ruirui ${ }^{1}$, He Yan ${ }^{1}$, Xu Changming ${ }^{1}$, Luo Yi ${ }^{2, *}$ \\ ${ }^{1}$ Wuhan Ucan Nano Fluid Technology Co. Ltd., Wuhan, China \\ ${ }^{2}$ Department of Chemistry and Chemical Engineering, Huazhong University of Science and Technology, Wuhan, China
}

Email address:

xinsha1226@163.com (Xin Sha), lrrui0707@163.com (Lu Ruirui),332625123@qq.com (He Yan), 461771873@qq.com (Xu Changming), Luoyi1951@163.com (Luo Yi)

${ }^{*}$ Corresponding author

\section{To cite this article:}

Xin Sha, Lu Ruirui, He Yan, Xu Changming, Luo Yi. Effect of the High Temperature Resistant Nano-Coolant on Automotive Engine Operation. Nanoscience and Nanometrology. Vol. 5, No. 1, 2019, pp. 1-5. doi: 10.11648/j.nsnm.20190501.11

Received: August 20, 2018; Accepted: December 13, 2018; Published: January 24, 2019

\begin{abstract}
An engine nano-coolant without agglomeration was developed, which was heated to 120 degrees and kept for 15 consecutive days, and has good anti-corrosion, and better thermal conductivity in flow compared with the conventional engine coolant. The results of engine bench scale test, vehicle driving and construction machinery test and exhaust emission test show that the fuel saving rate of the car on the expressway is $5-15 \%$, the fuel consumption of construction machinery decreases by $12.77 \%$, and the temperature of the water tank decreases by $8.17^{\circ} \mathrm{C}$ on average in summer without the help of natural wind. In addition, the emission of $\mathrm{CO}$ and $\mathrm{HC}$ during the driving process also decreases by $7.8-13 \%$ and $0-19 \%$ respectively, which proves that nano-fluids can significantly increase engine combustion efficiency, prevent engine from overheating at high temperature and reduce exhaust emissions, and will replace the ordinary ethylene glycol-water products as a new type of engine coolant with high thermal conductivity.
\end{abstract}

Keywords: Nano-Coolant, Automobile, Excavator, Fuel-Saving Rate, Tail Gas Pollution, Heat Exchange Efficiency

\section{Introduction}

Usually when the coolant temperature is $80-90^{\circ} \mathrm{C}$, the automobile engine is in the most fuel-efficient working state. In winter, the increase of vehicle fuel consumption is mainly due to the temperature of coolant is too low when the engine starts, which results in the increase of the viscous resistance of lubricating oil and the amount of fuel injected into the engine. In summer, the increase of engine energy consumption is mainly the power consumption of circulating cooler and frequent opening of vehicle air conditioner due to the high temperature of the water tank and the poor cooling effect of the coolant. Obviously, increasing the heat transfer rate of coolant is a simple and effective way to reduce engine fuel consumption. A large number of research results show that adding high thermal conductivity solid particles into the liquid can significantly improve the heat transfer performance of the fluid. Its characteristics will have more advantages used in the heavy duty diesel engine or high temperature turbine engine and it may replace the traditional ethylene glycol-water coolant.

At the same time, because of its instability, nano-particles can easily agglomerate at high temperatures, so previous studies on nano-heat exchangers have been limited to medium or low temperature heat transfer environments [1-5], while there were few reports on the use of coolants in automotive engine cooling [6-9].

A china invention patent technology "A preparation method and application of a nanometer heat transfer agent" [10] in 2016 provides a preparation method that can guarantees the long-term stability of nano-fluid in engine operating condition. The nano-coolant prepared according to this patent has the characteristics of continuous heating at $120^{\circ} \mathrm{C}$ and static holding 15 days without agglomeration. In 2017, the engine bench and vehicle driving test methods were used to test its performance, in order to evaluate the feasibility of its application in automobiles 


\section{Nano-Coolant and Test Method}

\subsection{Nano-Coolant}

Three kinds of nano-coolants with product numbers Ucan-185, Ucan-120 and Ucan-108 have been used various power machines. They are mainly composed of the namo-meter particles of metal or oxide, dispersion medium, polyols and corrosion inhibitors, and have high boiling point and low freezing point, and more high heat transfer efficiency as compared with the ordinary engine coolant without nano-particles. Their main physical and chemical properties are shown in Table 1.

Table 1. The physical \& chemical properties of the three nano-coolants and the ordinary coolants.

\begin{tabular}{|c|c|c|c|c|c|}
\hline Items & $\begin{array}{l}\text { Ordinary } \\
\text { coolant (A) }\end{array}$ & $\begin{array}{l}\text { Ordinary } \\
\text { coolant (B) }\end{array}$ & $\begin{array}{l}\text { Ucan-185 (Nanoparticle } \\
\text { content } 0.5 \% \text { ) }\end{array}$ & $\begin{array}{l}\text { Ucan-120 (Nanoparticle } \\
\text { content } 0.7 \%)\end{array}$ & $\begin{array}{l}\text { Ucan-108 (Nanoparticle } \\
\text { content } 1 \% \text { ) }\end{array}$ \\
\hline Boiling point $\left({ }^{\circ} \mathrm{C}\right)$ & 105 & 108 & 185 & 120 & 108 \\
\hline Freezing point $\left({ }^{\circ} \mathrm{C}\right)$ & -25 & -45 & $<-50$ & -50 & -25 \\
\hline Density $\left(\mathrm{kg} / \mathrm{m}^{3}\right)$ & 1090 & 1093 & 1119 & 1111 & 1090 \\
\hline Viscosity $108^{\circ} \mathrm{C}$ (Mpa.s) & 2.75 & 3.01 & 4.2 & 3.42 & 2.75 \\
\hline Thermal conductivity $80^{\circ} \mathrm{C}(\mathrm{W} / \mathrm{m} . \mathrm{k})$ & 0.45 & 0.4 & 0.46 & 0.55 & 0.67 \\
\hline
\end{tabular}

\subsection{Thermal Conductivity Measurement}

The thermal conductivity of sample is measured with the KD2 Pro Thermal Properties Analyzer (Decagon device, USA). The handled device measure the thermal conductivity values ranging from 0.02 to $2 \mathrm{~W} / \mathrm{mK}$ over the temperature range of $-50^{\circ} \mathrm{C}$ to $150^{\circ} \mathrm{C}$ with $5 \%$ accuracy [11]. It works based on the transient short hot-wire source method. The KD2 pro thermal analyzer complies with both ASTM D5334 standard and IEEE 442-1981 regulations.

\subsection{Engine Bench Scale Test}

The Gasoline engine total power test and Gasoline engine load characteristic test methods are used in the combustion efficiency comparison test. The instrument used is FC2000 gasoline engine automatic test system.

\subsection{The $100 \mathrm{~km}$ Driving Test of the Car}

The fuel consumption of the car running $100 \mathrm{~km}$ was evaluated by using Japan Ono FP - 2140 vehicle fuel consumption meter.

The both engine bench scale test and $100 \mathrm{~km}$ driving test comply with GB/T 14951-2007 standard (Automotive fuel-efficient technology assessment method).

\subsection{Detection of Tail Gas Pollutants}

The exhaust pollutant of gasoline engine was evaluated by using Free accelerate NHFD - 1 double idle speed emission test system.

The above tests are completed by Automobile Parts Test Center in china.

\subsection{Long-Distance Driving Tests of the Cars}

The test method is that four cars with different brands and displacements of Skoda 1.6L, BHMC 1.6L, Roewe 2.5L and Buick GL8 2.5L run along Wuhan Circle Highway. The distance of each circle is 187 kilometers and the speed is controlled at $100-110 \mathrm{~km} / \mathrm{h}$. After the vehicle is driven around the city once, the nano-coolant is replaced to continue to drive around the city, and the fuel consumption of each time is measured. The total mileage of this test is 2,057 kilometers after replacement.

\subsection{Engineering Machinery Test}

Date: August 2017;

Location: a construction site in Yichang city, Hubei province in china.

Test method: three rotary drilling RIGS and three excavators are selected for the test. The original coolant as reference sample and the namo-coolant Ucan 108 as substitute sample in the comparative test. The machine act is stopped when the temperature of water tank is no longer rinsing, and to measure and record the changes of temperature and fuel consumption respectively.

\section{Results and Discussion}

\subsection{Engine Bench Scale Test and 100km Driving Test}

\subsubsection{The Fuel Consumption Rate}

Table 2 shows the results of torque coefficient and fuel consumption rate obtained through the engine bench test. The average torque coefficient of Ucan-120 is a little bit higher and its fuel consumption rate reduced about $0.6-3.0 \%$ at 1600 $\mathrm{r} / \mathrm{min}-2900 \mathrm{r} / \mathrm{min}$ compared with ordinary coolant.

Because Ucan-120 can raises the cylinder temperature for $15^{\circ} \mathrm{C}$ compared with ordinary coolant, promoted the full combustion of fuel molecules, reduced emissions of harmful pollutants in exhaust. From Table 1, it can be seen that the thermal conductivity of nano-coolants is higher than that of ordinary coolants, which indicates that they have higher heat dissipation effect and lower power consumption in the process of circulating cooling.

Table 3 shows the results of the average fuel consumption rate obtained through the hundreds of kilometers road test. Compared with the ordinary coolant, when the speed change is $110 \mathrm{~km} / \mathrm{h} \sim 90 \mathrm{~km} / \mathrm{h}$, the oil consumption rate is reduced by $0.4 \% \sim 6.3 \%$ after used Ucan- 120 . 
Table 2. The comparative results of the Engine bench scale test for Ucan-120 and ordinary coolant.

\begin{tabular}{|c|c|c|c|c|c|}
\hline \multicolumn{6}{|c|}{ Test Items and Test Result } \\
\hline No & Test Items & Sample & Test conditions/ Technical requirements & \multicolumn{2}{|l|}{ Test Result } \\
\hline 1 & $\begin{array}{l}\text { Gasoline engine } \\
\text { total power } \\
\text { contrast test }\end{array}$ & Ucan-120 & $\begin{array}{l}\text { A power test on eight points (Throttle fully open, } \\
\text { Within the scope of work in the engine speed, which } \\
\text { in turn change speed, maximum speed of } 2900 \mathrm{r} / \mathrm{min} \text { ) }\end{array}$ & \multicolumn{2}{|c|}{$\begin{array}{l}\text { The average torque contrast coefficient: } 1.003 \\
\text { The average power contrast coefficient: } 1.000\end{array}$} \\
\hline 2 & $\begin{array}{l}\text { Gasoline engine } \\
\text { load characteristic } \\
\text { contrast test }\end{array}$ & Ucan-120 & $\begin{array}{l}\text { A load test on eight points (Keep the engine speed is } \\
\text { constant, starting from the } 30 \% \text { load to } 10 \% \text { load step } \\
\text { gradually up to } 100 \% \text { load) }\end{array}$ & $\begin{array}{l}\text { Speed } \mathrm{r} / \mathrm{min} \\
1600 \\
2000 \\
2900\end{array}$ & $\begin{array}{l}\text { The average change rate of fuel } \\
\text { consumption \% } \\
-3.0 \\
-2.0 \\
-0.6\end{array}$ \\
\hline Notes & $\begin{array}{l}\varphi=\frac{a-b}{a} \times 100 \% \\
\text { where, } \varphi=\text { Average } \\
\text { 2. Guangzhou pass } \\
\text { 3. During the samp } \\
\text { 40min; } 2000 \mathrm{r} / \mathrm{min} \text {, }\end{array}$ & $\begin{array}{l}\text { uel consump } \\
\text { iger car coo } \\
\text { test, the en } \\
0 \mathrm{~N} \cdot \mathrm{m}, 40 \mathrm{mi}\end{array}$ & $\begin{array}{l}\text { ion rate, } a=\text { Average fuel consumption of the Ucan-120, } \\
\text { in are used in the original machine cooling fluid, whose } \\
\text { ine was pre-grinded for } 2 \text { hours, and the grinding condit } \\
; 2900 \mathrm{r} / \mathrm{min}, 40 \mathrm{~N} \cdot \mathrm{m}, 40 \mathrm{~min} \text {; }\end{array}$ & $\begin{array}{l}=\text { Average fue } \\
\text { reezing point } \\
\text { ns and time w }\end{array}$ & $\begin{array}{l}\text { nsumption of the original machine. } \\
35^{\circ} \mathrm{C} \text {; } \\
\text { as follows: } 1600 \mathrm{r} / \mathrm{min},, 40 \mathrm{~N} \cdot \mathrm{m} \text {, }\end{array}$ \\
\hline
\end{tabular}

Table 3. Comparison test results of fuel consumption before and after the replacement of Ucan-120.

\begin{tabular}{|c|c|c|c|c|}
\hline \multicolumn{5}{|c|}{ Test items and results } \\
\hline NO. & Test items & Sample & Testing conditions & Results \\
\hline 1 & $\begin{array}{l}\text { Comparison test of the } \\
\text { fuel consumption of a } \\
\text { car running } 100 \mathrm{~km}\end{array}$ & Ucan-120 & $\begin{array}{l}\text { Measuring speed: } \\
\text { 90km/h, 110km/h } \\
\text { Measuring distance: } \\
25 \mathrm{~km} / \mathrm{time} \\
\text { Measurement: } 3 \text { times }\end{array}$ & $\begin{array}{l}\text { Average fuel consumption rate of } 90 \mathrm{~km} / \mathrm{h}:-0.4 \% \\
\text { Average fuel consumption rate of } 110 \mathrm{~km} / \mathrm{h}:-6.3 \%\end{array}$ \\
\hline Notes & \multicolumn{4}{|c|}{$\begin{array}{l}\text { The test vehicle is the Gm buick GL8, with an oil displacement of } 2.4 \mathrm{~L} \text {, and the test section is the guanghui section of jiguang expressway; } \\
\varphi=\frac{s-b}{\mathrm{a}} \times 100 \% \\
\text { where, } \varphi=\text { Average fuel consumption rate, a }=\text { Average fuel consumption of the Ucan- } 120, \mathrm{~b}=\text { Average fuel consumption of the original machine } \\
3 \text {. The original machine test to join passenger car coolant, freezing point }-35^{\circ} \mathrm{C} \text {, and before the test, the engine cooling water channel are } \\
\text { cleaned; } \\
\text { 4. The sample test vehicle travels } 200 \mathrm{~km} \text { in advance; }\end{array}$} \\
\hline
\end{tabular}

\subsubsection{Exhaust Pollutant Emission}

Table 4 show that the content of CO decreased by $10-13.2 \%$ and HC decreased by $0-20 \%$ in tail gas in the engine bench test, and the $\mathrm{CO}$ decreased by $7.8-13 \%$ and $\mathrm{HC}$ decreased by $0-19 \%$ in the car running test.

Table 4. The change of exhaust emissions of the engine bench and car driving tests before and after replacing Ucan-120.

\begin{tabular}{|c|c|c|c|c|c|}
\hline \multirow[b]{2}{*}{ test method } & \multirow[b]{2}{*}{ Test items } & \multicolumn{2}{|l|}{ Before using Ucan-120 } & \multicolumn{2}{|l|}{ After using Ucan-120 } \\
\hline & & $\begin{array}{l}\text { high idle speed }(2500 \\
\text { r/min) }\end{array}$ & $\begin{array}{l}\text { low idle speed }(800 \\
\text { r/min) }\end{array}$ & $\begin{array}{l}\text { high idle speed }(2500 \\
\text { r/min) }\end{array}$ & $\begin{array}{l}\text { low idle speed }(800 \\
\text { r/min) }\end{array}$ \\
\hline \multirow{2}{*}{ engine bench } & $\mathrm{CO}(\%)$ & 0.040 & 0.053 & 0.036 & 0.046 \\
\hline & $\mathrm{HC}\left(10^{-6}\right)$ & 4.00 & 6.67 & 4.00 & 5.33 \\
\hline \multirow{2}{*}{ car driving } & $\mathrm{CO}(\%)$ & 0.090 & 0.100 & 0.083 & 0.087 \\
\hline & $\mathrm{HC}\left(10^{-6}\right)$ & 7.00 & 8 & 5.67 & 8 \\
\hline
\end{tabular}

\subsection{Long-distance Driving Tests of the Cars}

The collected test data of the vehicles are analyzed and processed by mathematical statistics method, the probability distribution curve of optimal fuel saving rate of Ucan-120 is showed in Figure 1.

\begin{tabular}{|c|c|}
\hline Fitting equation & $y=y 0+A^{*} \exp \left(-0.5^{\star}((x-x c) / w)^{\wedge} 2\right)$ \\
\hline$y 0$ & 0.09091 \\
\hline$x c$ & 9 \\
\hline$w$ & 1.05 \\
\hline$A$ & 0.27273 \\
\hline
\end{tabular}




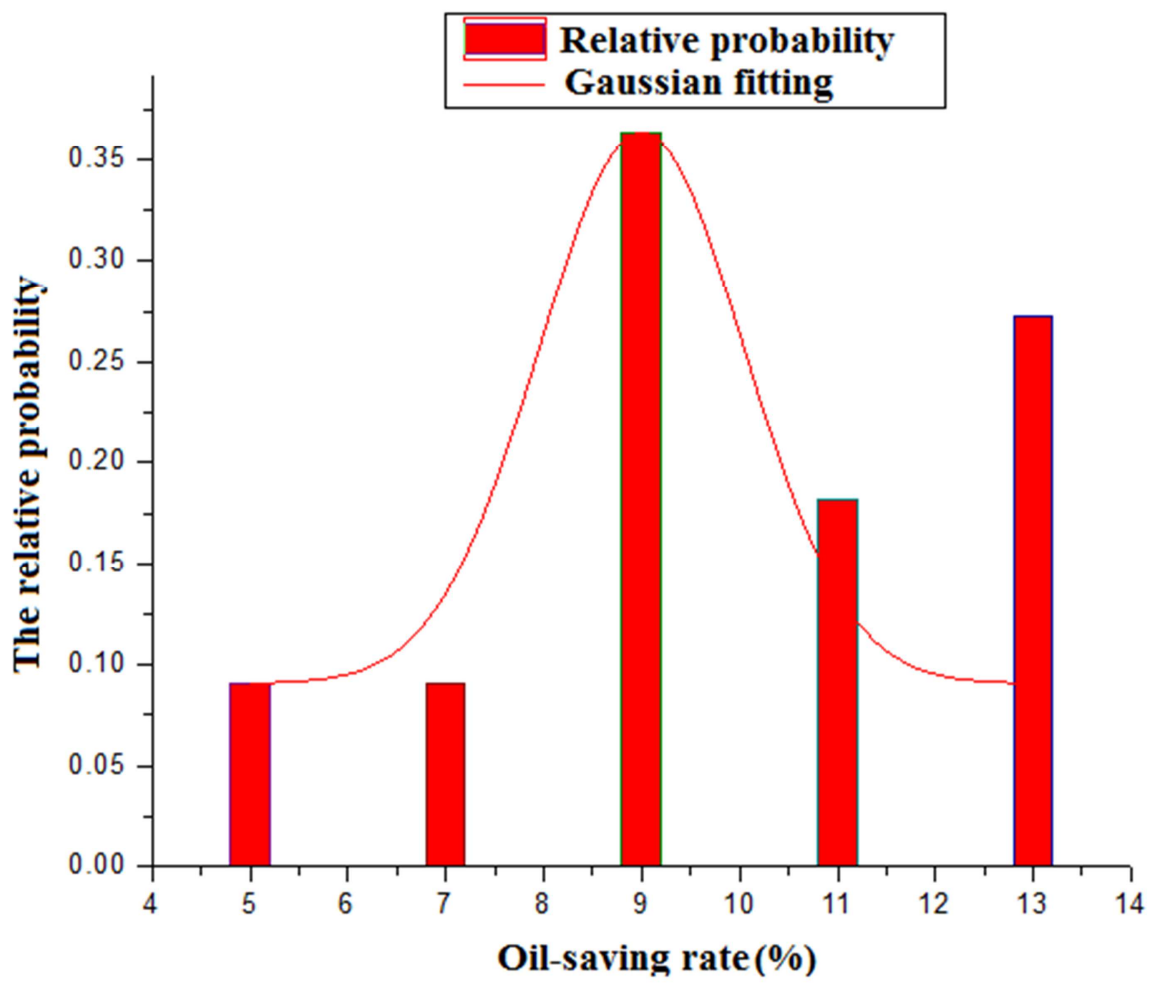

Figure 1. Probability distribution curve of optimal saving oil rate of Ucan-120.

Figure 1 show that compared with ordinary coolant, the oil saving rate after replaced Ucan-120 is mainly distributed around $9 \%$, and probability distribution range is approximately $5-15 \%$.

\subsection{Engineering Machinery Test}

The result of both the heat dissipation of water tank and the fuel saving rate of the machines before and after replaced the nano-coolants are shown in table 5.

Table 5. The test result of the Engineering machinery test after replaced the nano-coolants.

\begin{tabular}{lllllll}
\hline Machinery type & Namo-coolant & $\begin{array}{l}\text { Engine } \\
\text { power }\end{array}$ & $\begin{array}{l}\text { Temperature of water } \\
\text { tank before replacing } \\
\text { nano- coolant }\end{array}$ & $\begin{array}{l}\text { Temperature of water } \\
\text { tank after replacing } \\
\text { nano-coolant }\end{array}$ & $\begin{array}{l}\text { The change of } \\
\text { temperature }\end{array}$ & $\begin{array}{l}\text { The change rate of } \\
\text { fuel consumption }\end{array}$ \\
\hline Drilling machinery & Ucan-120 & $298 \mathrm{KW}$ & $96^{\circ} \mathrm{C}$ & $87^{\circ} \mathrm{C}$ & $-9{ }^{\circ} \mathrm{C}$ & $-18.5^{\circ}$ \\
Drilling machinery & Ucan-120 & $133 \mathrm{kw}$ & $98^{\circ} \mathrm{C}$ & $88^{\circ} \mathrm{C}$ & $-10^{\circ} \mathrm{C}$ & - \\
Drilling machinery & Ucan-108 & $246 \mathrm{KW}$ & $103^{\circ} \mathrm{C}$ & $90^{\circ} \mathrm{C}$ & $-13^{\circ} \mathrm{C}$ & - \\
Excavator & Ucan-120 & $45 \mathrm{kw}$ & $89^{\circ} \mathrm{C}$ & $83^{\circ} \mathrm{C}$ & $-6^{\circ} \mathrm{C}$ & $-7.65 \%$ \\
Excavator & Ucan-120 & $45 \mathrm{kw}$ & $84^{\circ} \mathrm{C}$ & $79^{\circ} \mathrm{C}$ & $-5^{\circ} \mathrm{C}$ & $-12.16 \%$ \\
Excavator & Ucan-108 & $110 \mathrm{kw}$ & $98^{\circ} \mathrm{C}$ & $92^{\circ} \mathrm{C}$ & $-6^{\circ} \mathrm{C}$ & - \\
average value & & & & & $-8.17^{\circ} \mathrm{C}$ & $-12.77 \%$ \\
\hline
\end{tabular}

The construction machinery can not use the wind to help the water tank heat dissipation in the process of vehicle driving. Therefore, the heat transfer efficiency of coolant is very important to ensure the normal operation of the machine in $40-50{ }^{\circ} \mathrm{C}$ environment in summer. Table 5 shows that nano-coolant with high thermal conductivity can reduce the temperature of water tank by $5-13^{\circ} \mathrm{C}$ and the average fuel consumption of these machines by $12.77 \%$ compared with ordinary cooling liquid, Obviously, it is a very effective engine high temperature coolant.

\section{Conclusion}

The results of engine bench test, vehicle driving and construction machinery test and exhaust emission test show that the fuel saving rate of the car on the expressway is $5-15 \%$, the fuel consumption of construction machinery decreases by $12.77 \%$, and the temperature of the water tank decreases by $8.17^{\circ} \mathrm{C}$ on average in summer without the help of natural wind. In addition, the emission of $\mathrm{CO}$ and $\mathrm{HC}$ during the driving process also decreases by $7.8-13 \%$ and $0-19 \%$ respectively, which proves that nano-fluids can 
significantly increase engine combustion efficiency, prevent engine from overheating at high temperature and reduce exhaust emissions, and will replace the existing ethylene glycol-water products as a new type of engine coolant with high thermal conductivity.

\section{References}

[1] P Keblinski, J A Eastman, D G Cahill. "Nanofluids for thermal transport”, Materials Today, vol. 8, no. 6, 36-44. 2005.

[2] S Choi. "Nanofluids: a new field of scientific research and innovative applications", Heat Transfer Engineering, vol 29 no 5, 429-431, 2008.

[3] W Yu, D M France, J L Routbort. "Review and comparison of nanofluid thermal conductivity and heat transfer enhancements", Heat Transfer Engineering, vol 29 no 5, 432-460, 2008.

[4] D Wen, G Lin, S Vafaei. "Review of nanofluids for heat transfer applications", Particuology, vol 7 no 2, 141-150, 2007.

[5] S Choi. "Nanofluids for improved efficiency in cooling systems for heavy vehicle systems review" USA: Argonne National Laboratory, 18-20, 2006.
[6] H. Xie, W. Yu, Y. Li, L. Chen. "Discussion on the thermal conductivity enhancement of nanofluids", Nanoscale Res. Lett. vol 6 no $1,1-12,2011$.

[7] A. N. Al-Shamani, M. H. Yazdi, M. Alghoul, A. M. Abed, M. Ruslan, S. Mat, K. Sopian. "Nanofluids for improved efficiency in cooling solar collectors-a review", Renew. Sust. Energ. Rev. vol 38, 348-367, 2014.

[8] M. J. Pastoriza-Gallego, L. Lugo, D. Cabaleiro, J. L. Legido, M M. Piñeiro. "Thermophysical profile of ethylene glycol-based ZnO nanofluids", J. Chem. Thermodyn. Vol 73, 23-30, 2014.

[9] B. Buonomo, O. Manca, L. Marinelli, S. Nardini. "Effect of temperature and sonication time nanofluid thermal conductivity measurements by nano-flash method", Appl. Therm. Eng. Vol 91, 181-190, 2015.

[10] Q S He, Y Luo. "The preparation method and application for a nanofluid heat transfer agent”, CN 201610374971.1. 2016-05-31.

[11] D. Devices. KD2 Pro Thermal Properties Analyzer Operator's Manual Version 4, Decagon Devices, Inc., Pullman, WA, USA, 1-67, 2015. 